\title{
Influence of molecular weight on dielectric properties and piezoelectric constant of poly(vinylidene fluoride) membranes obtained by electrospinning*)
}

\author{
Aminatul Sobirah Zahari ${ }^{1)}$ (ORCID ID: 0000-0002-8126-3851), Muhammad Hafiz Mazwir ${ }^{1)}{ }^{* *)}$ (0000-0003-2010-1928), \\ Izan Izwan Misnon ${ }^{1)}(0000-0001-7226-5049)$
}

DOI: dx.doi.org/10.14314/polimery.2021.10.4

\begin{abstract}
A significant influence of the molecular weight on the dielectric properties and piezoelectric constant of poly(vinylidene fluoride) (PVDF) membranes obtained by electrospinning was demonstrated. Electrochemical impedance spectroscopy and $d_{33}$ meter were used to evaluate dielectric properties and piezoelectric constant respectively. The presence of the $\beta$-phase was determined by Fourier transform infrared spectroscopy (FTIR) and X-ray diffraction (XRD). The membranes with the lowest molecular weight $(180,000 \mathrm{~g} / \mathrm{mol})$ possessed the best dielectric properties. They also had the highest piezoelectric constant $(21 \mathrm{pC} / \mathrm{N})$ and dielectric constant $(2.9$ at $50 \mathrm{~Hz})$ as well as the highest $\beta$-phase content $(80.25 \%)$.
\end{abstract}

Keywords: piezoelectric constant, poly(vinylidene fluoride), electrospinning, molecular weight.

\section{Wpływ masy cząsteczkowej na właściwości dielektryczne i stałą piezoelektryczną membran poli(fluorku winylidenu) otrzymanych metodą elektroprzędzenia}

Streszczenie: Wykazano istotny wpływ masy cząsteczkowej na właściwości dielektryczne i stałą pie-
zoelektryczną membran poli(fluorku winylidenu) (PVDF) otrzymanych metodą elektroprzędzenia.
Do oceny stałej piezoelektrycznej i właściwości dielektrycznych stosowano, odpowiednio, miernik $d_{33}$
i spektroskopię impedancyjną. Obecność fazy $\beta$ określono za pomocą spektroskopii w podczerwieni
z transformacją Fouriera (FTIR) i dyfrakcji rentgenowskiej (XRD). Membrany o najmniejszej masie czą-
steczkowej (180 $000 \mathrm{~g} / \mathrm{mol}$ ) charakteryzowały się najlepszymi właściwościami dielektrycznymi. Miały
również największą stałą piezoelektryczną $(21 \mathrm{pC} / \mathrm{N})$ i stałą dielektryczną (2,9 przy $50 \mathrm{~Hz}$ ) oraz najwięk-
szą zawartość fazy $\beta(80,25 \%)$.

Słowa kluczowe: stała piezoelektryczna, poli(fluorek winylidenu), elektroprzędzenie, masa cząsteczkowa.

Poly(vinylidene fluoride) (PVDF) is a semicrystalline polymer with an excellent piezoelectric and dielectric properties, thus it is very useful in electronics as sensors, actuators and capacitors [1, 2]. It has a repeating unit of $-\mathrm{CH}_{2} \mathrm{CF}_{2}-$ monomer which acts as a dipole due to the fluorine's highest electronegativity in the periodic table. The arrangement of these repeating units in PVDF directly controls the net dipole moment and orientation of dipoles.

\footnotetext{
1) Faculty of Industrial Sciences and Technology, Universiti Malaysia Pahang, Lebuhraya Tun Razak, 26300 Kuantan, Pahang, Malaysia.

*) Material contained in this article was presented at the 1st Malaysia International Conference on Nanotechnology \& Catalysis (MICNC 2021), 1-3 September 2021, Malaya, Malaysia. **) Author for correspondence: muhammadhafiz@ump.edu.my
}

There are three well-known PVDF crystalline phases, $\alpha, \beta$ and $\gamma$, where $\alpha$-phase is the most common in melt crystallization. High temperature and pressure are the only factors that induce the $\gamma$-phase to develop whereas the $\beta$-phase is produced via poling or annealing at high pressure. Due to the orientation of all dipole chains in the same direction, the b-phase PVDF with high dipole moment induces strong spontaneous polarization in a unit cell, which is a desirable feature of pyro-, ferroand piezoelectric properties [3-5]. Besides, Martion et al. reported higher piezoelectric constant of the PVDF membrane with the greatest $\beta$-phase content than the membrane with lower $\beta$-phase content [6]. Thus, most of researchers focused on creating high $\beta$-phase content in PVDF by using different methods, such as mechanical stretching, additives, electrospinning and electrical poling [7]. 
Recently, the electrospinning process allows for synthesis of PVDF membranes which increased the formation of $\beta$-phase $[6,8]$. In addition, it is an easy and inexpensive method of producing ultrafine fibers with sizes ranging from a few micrometers to hundreds of nanometers $[9,10]$. Moreover, electrospun nanofibers have onedimensional morphology, high surface area, extraordinary length and high porosity.

Since recognizing the effect of intrinsic characteristics such as molecular weight and crystal structure are crucial to obtain high piezoelectric constant and dielectric properties of PVDF, in this study we focused on the influence of the molecular weight of PVDF on these properties.

\section{EXPERIMENTAL PART}

\section{Materials}

Poly(vinylidene fluoride) (PVDF) with molecular weights of 180,000; 275,000; 530,000 and 1,000,000 g/mol were purchased from Sigma-Aldrich whereas R\&M Chemicals provided N,N-dimethylformamide (DMF) and acetone.

\section{Methods}

PVDF granules were dissolved in a 70:30 volumetric ratio of DMF and acetone to produce solutions of PVDF with various molecular weights at a concentration of $13 \mathrm{wt} \%$. PVDF solutions were swirled thoroughly for 12 hours at $70^{\circ} \mathrm{C}$. DMF and acetone both have high dielectric constant in the range of 20.7-30.7, so it makes them suitable for electrospinning. The electrospinning parameters were established to be $13 \mathrm{kV}$ applied voltage, $15 \mathrm{~cm}$ distance between collector and needle, $2.5 \mathrm{ml} / \mathrm{h}$ PVDF solution flow rate, $5 \mathrm{ml}$ syringe and 20 -gauge needle were used.

The JSM-7800F field emission scanning electron microscope (FESEM), which delivers images at very high magnification and resolution $(1.3 \mathrm{~nm}$ at $30 \mathrm{kV})$, was used to study the morphology of PVDF membranes. All membrane samples were cut into squares with a length of $3 \mathrm{~cm}$ and the average membrane diameter of the electrospun PVDF was measured on 30,000× magnified FESEM images. Fourier transform infrared spectroscopy (FTIR) and X-ray diffraction (XRD) were used for examination of the crystalline phases of PVDF. ATR-FTIR measurements were taken from 1500 to $400 \mathrm{~cm}^{-1}$ using the
Perkin-Elmer Spectrum 100 apparatus in attenuated total reflection (ATR) mode. The Bruker D8 Advance X-Ray Diffractometer was employed for XRD, with a step size (2 $\theta$ ) of $0.02^{\circ}$, current and voltage of $40 \mathrm{~mA}$ and $40 \mathrm{kV}$ respectively. The area and thickness of electrospun membranes were measured and after sandwiching between two stainless steel electrodes their dielectric properties were specified using electrochemical impedance spectroscopy (EIS) at ambient temperature. The dielectric constant, $\varepsilon^{\prime}$, and dielectric loss, tan $\delta$, were calculated from complex impedance EIS data using Equations 1-3 [11].

$$
\begin{gathered}
\varepsilon^{\prime}=\frac{t}{\omega A \varepsilon_{0}} \frac{Z^{\prime \prime}}{Z^{\prime 2}+Z^{\prime 2}} \\
\varepsilon^{\prime \prime}=\frac{t}{\omega A \varepsilon_{0}} \frac{Z^{\prime}}{Z^{\prime 2}+Z^{\prime 2}} \\
\tan \delta=\frac{\varepsilon^{\prime \prime}}{\varepsilon^{\prime}}
\end{gathered}
$$

where:

$t$ - thickness of the electrospun membrane, $A$ - crosssectional area of the membrane, $\omega$ - angular frequency, $\varepsilon_{0}$ - permittivity of free space, $Z^{\prime}$ - real part of the impedance and $Z^{\prime \prime}$ - imaginary part of the impedance.

Finally, the piezoelectric constants of the electrospun PVDF membranes were measured using commercial quasi-static $d_{33}$ meter (90-2030, APC International, Ltd) at $50 \mathrm{~Hz}$ frequency. This instrument is able to directly measure the $d_{33}$ values of piezoelectric materials.

\section{RESULTS AND DISCUSSION}

FESEM images of electrospun PVDF membranes with various molecular weight and the same concentration are shown in Figure 1. The membranes had high porosity and linked pores. The high fiber porosity increases the surface area. Furthermore, due to the interaction of electrostatic forces between the needle and the collector during electrospinning, the PVDF membrane comprised of uniform fibers rather than beads $[12,13]$. Table 1 illustrates the calculated fiber diameters; it is shown that as the PVDF molecular weight increased, the average diameters of electrospun fibers increased as well. The 180,000 g/mol PVDF membrane had the least average fiber diameter of $72.84 \mathrm{~nm}$ while the $530,000 \mathrm{~g} / \mathrm{mol}$ PVDF membrane had the greatest one. The molecular weight increase from 180,000 to 530,000 g/mol led to the increase of the diameter of electrospun fibers by almost $41 \%$, from

$\mathrm{T}$ a b 1 e 1. Average fiber diameters, fraction of $\beta$-phase and piezoelectric constant of the electrospun PVDF membranes

\begin{tabular}{c|c|c|c}
\hline PVDF molecular weight, $\mathrm{g} / \mathrm{mol}$ & Fiber diameter, $\mathrm{nm}$ & $F_{\beta^{\prime}} \%$ & Piezoelectric constant, $d_{33^{\prime}} \mathrm{pC} / \mathrm{N}$ \\
\hline 180,000 & 72.84 & 80.25 & 21.0 \\
275,000 & 113.42 & 62.89 & 15.9 \\
530,000 & 175.24 & 66.53 & 17.0 \\
$1,000,000$ & 136.13 & 54.42 & 14.5 \\
\hline
\end{tabular}


a)

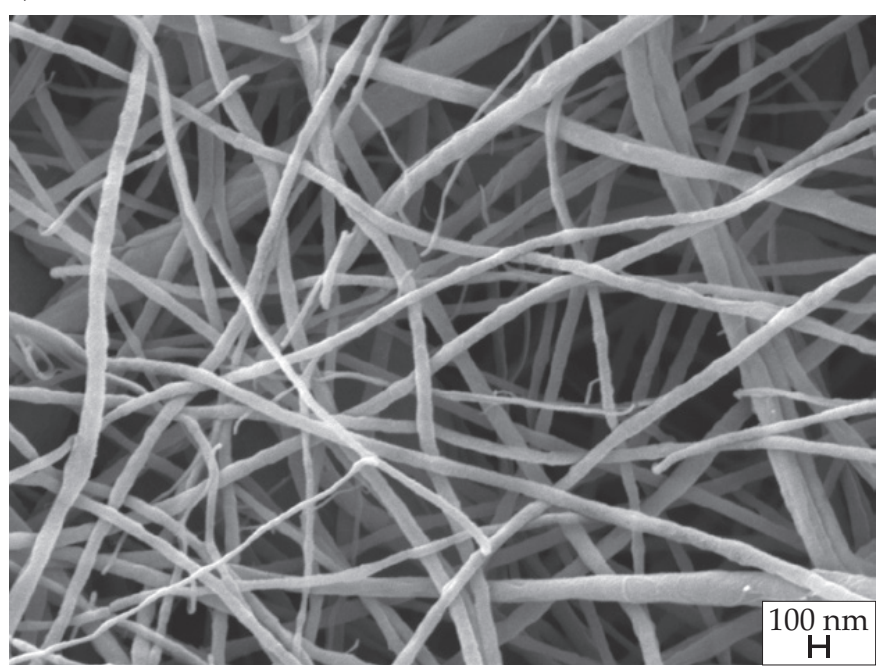

c)

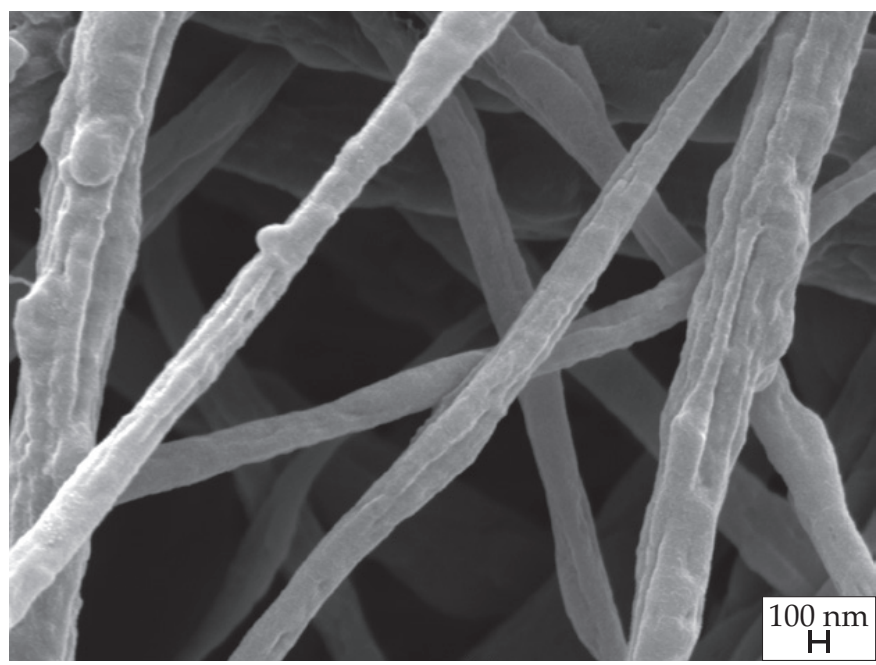

b)

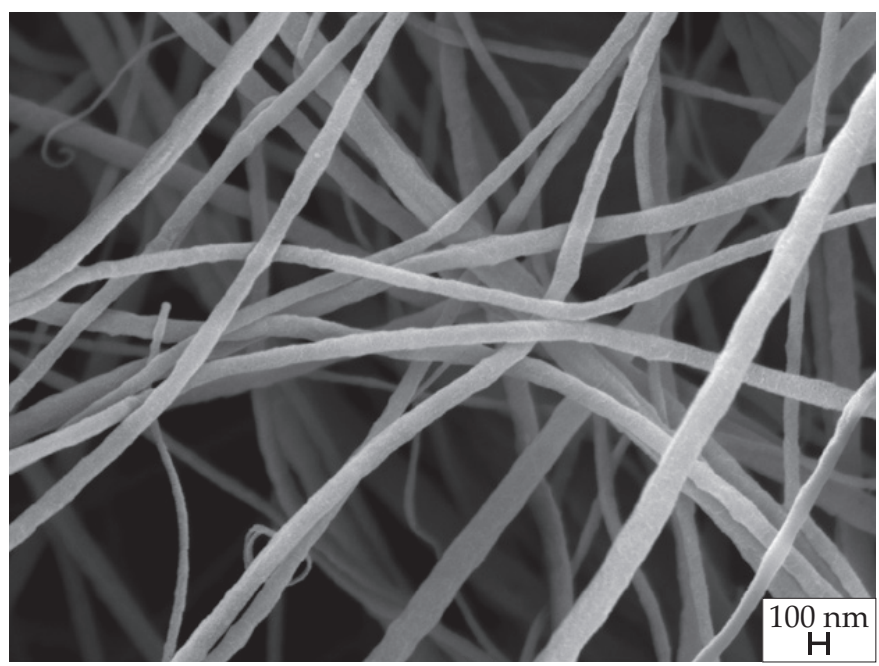

d)

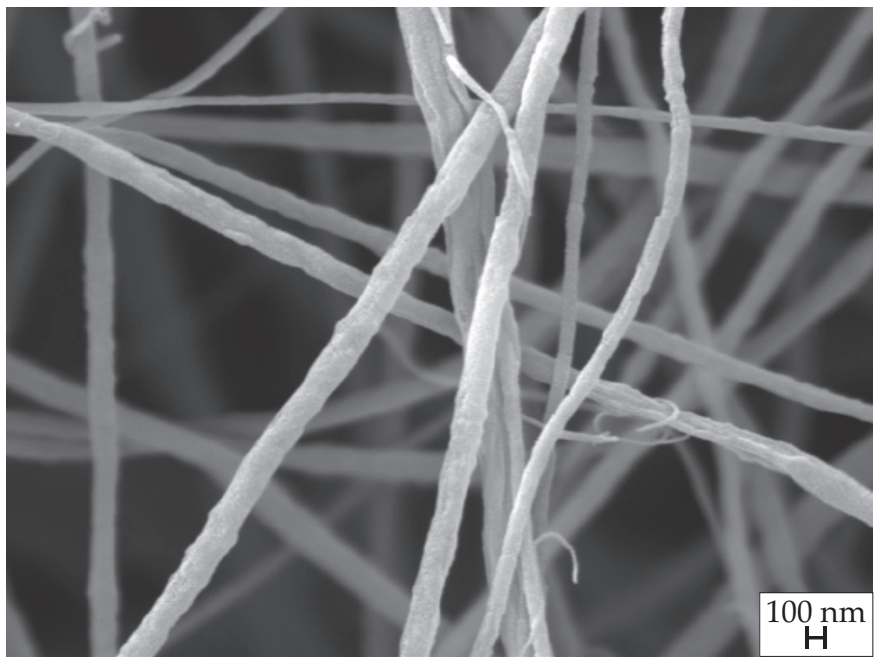

Fig. 1. FESEM images of electrospun PVDF membranes of: a) 180,000 g/mol, b) 275,000 g/mol, c) 530,000 g/mol, d) 1,000,000 g/mol; all images are reported at scales of $100 \mathrm{~nm}$

$72.84 \mathrm{~nm}$ to $175.24 \mathrm{~nm}$, while increasing the molecular weight up to $1,000,000 \mathrm{~g} / \mathrm{mol}$ resulted in thinner fibers. The width of the diameter of 530,000 g/mol PVDF membrane was caused by an unstable electrical force during the fabrication of electrospun PVDF [2].

As shown in the ATR-FTIR spectra in Figure 2, two kinds of crystalline phases appeared in electrospun PVDF: $\alpha$-phase and $\beta$-phase. The $\beta$-phase was present most frequently in all samples of electrospun PVDF. Therefore, the $\beta$-phase was successfully obtained by electrospinning without the need to do post-treatment such as drawing and annealing. The $\beta$-phase crystals existing in a material $[2,14-15]$ leads to efficient piezoelectricity and dielectric properties. At 614, 763 and $970 \mathrm{~cm}^{-1}$, the characteristic bands corresponded to the $\alpha$-phase $[2,9]$. Besides, the absorption peaks at 482, 510, 599, 840, 1275 and $1400 \mathrm{~cm}^{-1}$ corresponded to the $\beta$-phase $[1,6,8,16-18]$.

The absorption band at $763 \mathrm{~cm}^{-1}$ was associated with the rocking vibration while $\mathrm{CH}_{2}$ twisting was associated at $970 \mathrm{~cm}^{-1}$. At $1400 \mathrm{~cm}^{-1}$, PVDF membranes presented

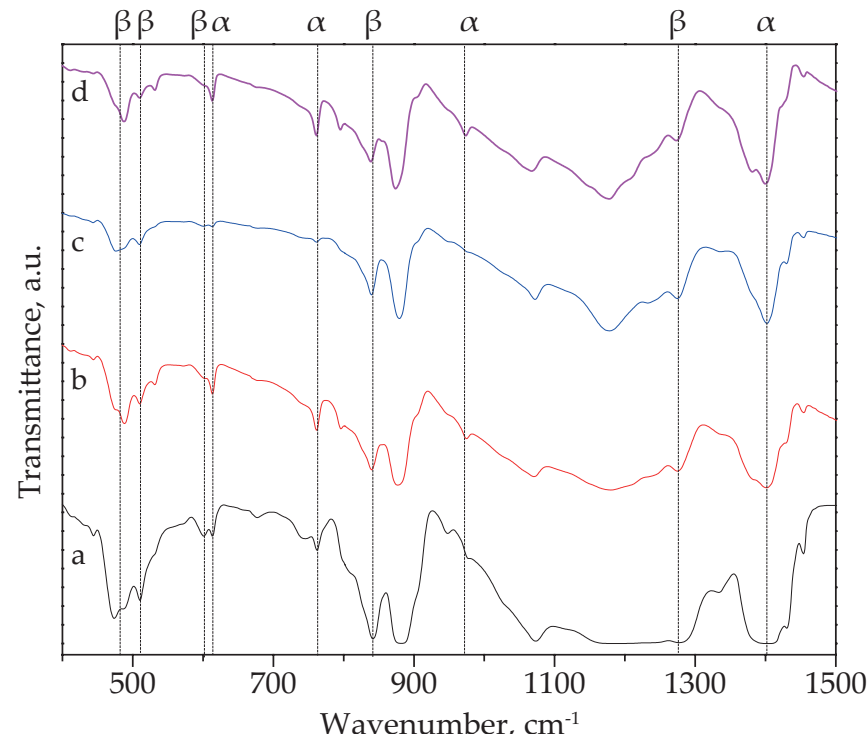

Fig. 2. FTIR spectra of PVDF membranes with molecular weight: a) $180,000 \mathrm{~g} / \mathrm{mol}$, b) $275,000 \mathrm{~g} / \mathrm{mol}$, c) $530,000 \mathrm{~g} / \mathrm{mol}$, d) $1,000,000 \mathrm{~g} / \mathrm{mol}$ 
sharp absorption which implied an in-plane bending vibration of $-\mathrm{CH}_{2}$ [19]. A combined form of $\mathrm{CH}_{2}$ rocking and $\mathrm{CF}_{2}$ asymmetric stretching vibration was assigned to the band at $840 \mathrm{~cm}^{-1}$, while a $\mathrm{CF}_{2}$ bending was allocated to the band at $510 \mathrm{~cm}^{-1}$ [20-21]. Moreover, the fraction of $\beta$-phase, $F_{\beta}$, could be determined by FTIR data (Table 1). The largest $\beta$-phase content $(80.25 \%)$ characterized the 180,000 $\mathrm{g} / \mathrm{mol}$ PVDF membrane and decreased with increasing molecular weight. Thus, this indicates that molecular weight influenced the development of the $\beta$-phase in PVDF during electrospinning.

XRD results (Figure 3 ) show the existence of both $\alpha$ - and $\beta$-phase in electrospun PVDF membranes. The $\alpha$-phase of PVDF had peaks at $18.4^{\circ}(020)$ and $20.13^{\circ}(110)$ while the $\beta$-phase of PVDF had peaks at $20.8^{\circ}(110)$ and $20.0^{\circ}$ (110) [2, 22-27]. 180,000 g/mol PVDF membrane had a diffraction peak at $2 \theta=21.0^{\circ}$, equivalent to the overlapping (110) and (200) reflections of $\beta$-crystals with low intensity diffraction peak at $18.4^{\circ}$. For electrospun membrane, notably electrospun PVDF with a molecular weight of $530,000 \mathrm{~g} / \mathrm{mol}$, the peak at $18.4^{\circ}$ decreased in intensity. Then, the peak intensity at $20.0^{\circ}$ for the $180,000 \mathrm{~g} / \mathrm{mol}$ PVDF membrane was more precise than the peak intensity at $20.8^{\circ}$. However, there was no peak corresponding to $\beta$-phase at $20.8^{\circ}$ for the $1,000,000 \mathrm{~g} / \mathrm{mol}$ PVDF membrane [28]. Moreover, the electrospun 180,000 g/molPVDF membrane was distinguished from the other membranes with the sharpest peak at $2 \theta=20.0^{\circ}$ and $21.0^{\circ}$, which indicated the membrane greater $\beta$-phase content. As a result, the calculated $\beta$-phase fraction $\left(F_{\beta}\right.$, Table 1$)$ was verified. Therefore, the molecular weight of electrospun PVDF that produces the maximum $\beta$-phase content is $180,000 \mathrm{~g} / \mathrm{mol}$.

Figures $4 \mathrm{a}$ and b illustrate the dielectric constant, $\varepsilon^{\prime}$, and dielectric loss, $\tan \delta$, as a function of frequency. It can be established that the dual dielectric properties of

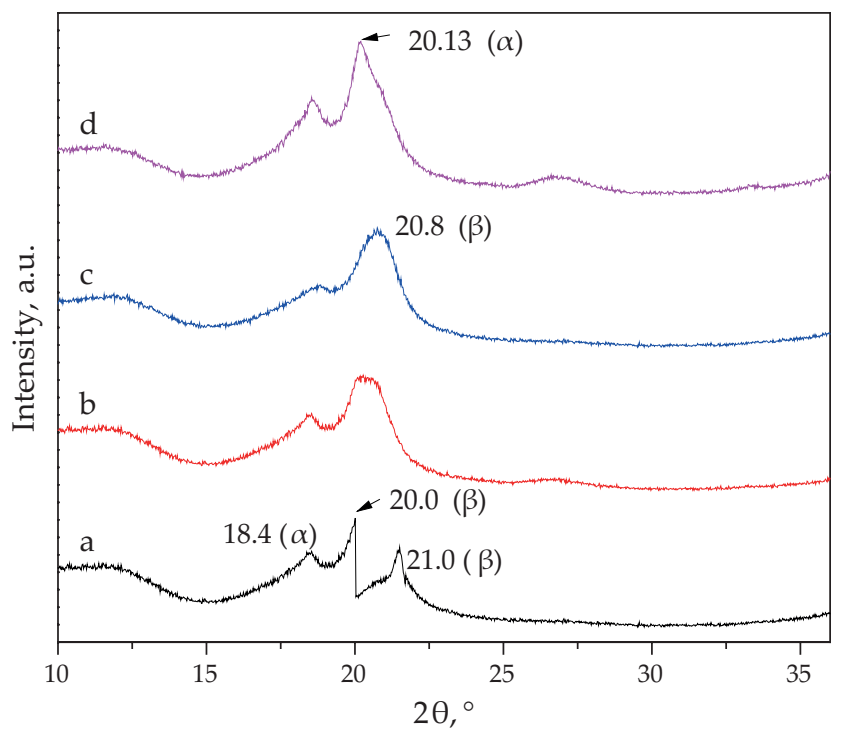

Fig. 3. XRD graph of PVDF membranes with: a) $180,000 \mathrm{~g} / \mathrm{mol}$, b) $275,000 \mathrm{~g} / \mathrm{mol}$, c) $530,000 \mathrm{~g} / \mathrm{mol}$, d) $1,000,000 \mathrm{~g} / \mathrm{mol}$

all membranes decreased with increasing of frequency. It is the result of dipoles orientation movement in the crystalline-amorphous of PVDF [29]. The $\varepsilon^{\prime}$ of all membranes was exceptionally high in the low frequency region, as seen in Figure $4 a$, however, as the frequency was risen, the dielectric constant dropped due to the inability of the electric dipole to cooperate with the change of electric field applied. Moreover, the $\varepsilon^{\prime}$ of these electrospun PVDF membranes against the frequency exhibited and evident reduction around $150 \mathrm{~Hz}$ until the end of the frequency $(100 \mathrm{kHz})$. The $\varepsilon^{\prime}$ at frequency of $50 \mathrm{~Hz}$ for all the samples was decreased which is consistent with the $F_{\beta}$ content in electrospun PVDF membranes, indicating that the molecular weight influences the dielectric constant. Thus, 180,000 g/mol PVDF is the optimum molecu-
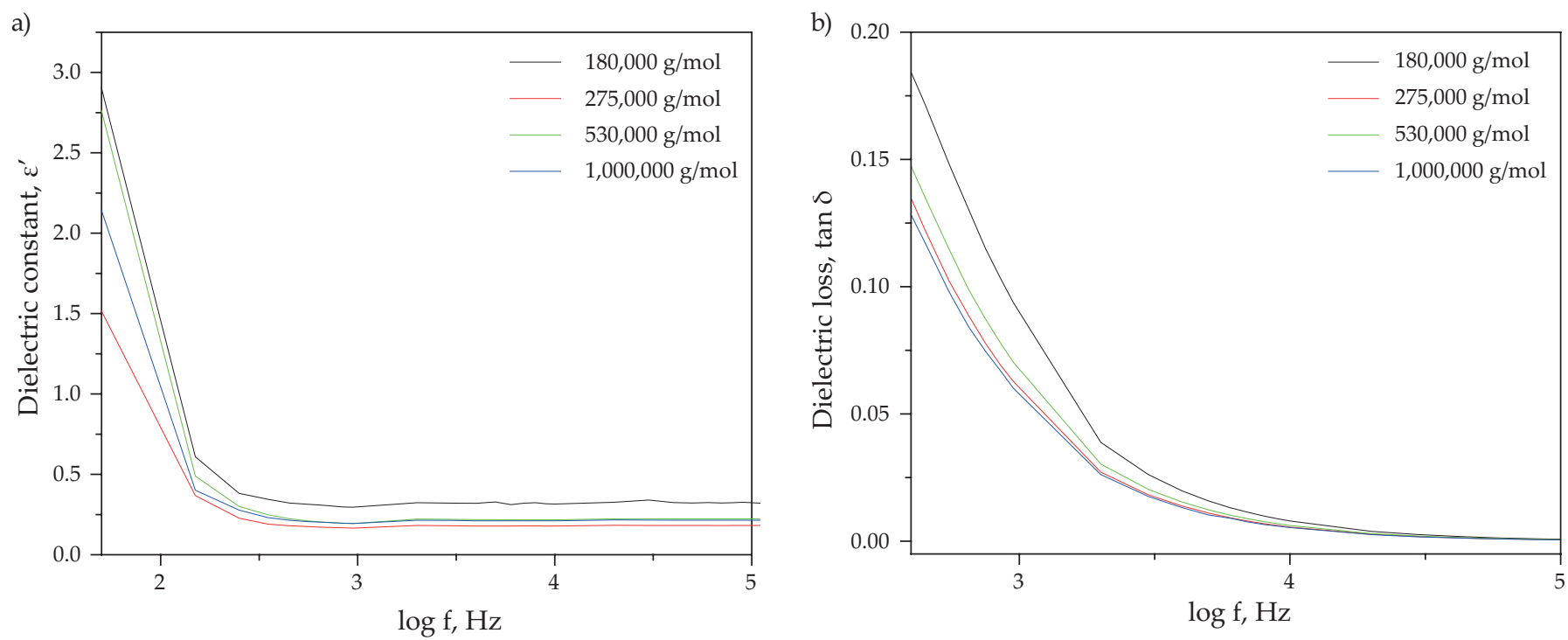

Fig. 4. The dielectric constant (a) and the dielectric loss (b) of electrospun PVDF membrane at ambient temperature with various molecular weights 
lar weight to get a high dielectric constant. The crystalline $\beta$-phase of PVDF is most likely responsible for the significant effect of the $\varepsilon^{\prime}[20,29]$.

Dielectric loss is defined as the amount of power loss in dielectric material under the influence of the applied voltage of the field. It can change with frequency, temperature, composition, orientation, pressure and molecular structure of a material. As shown in Figure $4 b$, the dielectric loss, $\tan \delta$, curves of the electrospun PVDF membranes decreased with an increase of frequency. However, all the samples showed constant tan $\delta$ values throughout the frequency at the range $1-100 \mathrm{kHz}$. For all membranes, energy dissipation was extremely low for $\tan \delta$ calculated below 0.2. Because the dipoles responsible for polarization could no longer follow the oscillation of the electric field at these frequencies in the presence of alternating current, the tan $\delta$ continued to drop down with frequency [29]. Additionally, the tan $\delta$ curves of the electrospun PVDF membranes were comparable and there was just a minor difference at the high frequency. Consequently, the dissipation factor of PVDF membranes is unaffected by their molecular weight.

Finally, the piezoelectric constant, $d_{33}$, was measured and listed in Table 1 . With $21 \mathrm{pC} / \mathrm{N}$, the electrospun 180,000 g/mol PVDF membrane demonstrated the highest piezoelectric constant while the lowest piezoelectric constant belonged to the electrospun 1,000,000 g/mol PVDF membrane $(14.5 \mathrm{pC} / \mathrm{N})$. The $d_{33}$ of PVDF membranes are consistent with changes of $\varepsilon^{\prime}$ and $\tan \delta$, showing that the lowest molecular weight has the highest $d_{33}, \varepsilon^{\prime}$ and $\tan \delta$ since it has the highest $\beta$-phase content. Thus, the crystalline $\beta$-phase is responsible for the increase of piezoelectric constant in PVDF. The $\beta$-phase is the most attractive conformation with the greatest polarity, hence, a piezoelectric effect depending on their molecular structure [14-15].

\section{CONCLUSION}

PVDF membranes with a high $\beta$-phase content were successfully synthesized using electrospinning process. PVDF molecular weight affected membrane morphologies and its decrease reduced the average fiber diameter. The molecular weight greatly impacted the dielectric properties and piezoelectric constant. The studied PVDF membrane with molecular weight of $180,000 \mathrm{~g} / \mathrm{mol}$ showed the highest $\beta$-phase content and had the highest dielectric properties and piezoelectric constant.

\section{ACKNOWLEDGEMENTS}

The authors would like to gratitude to the Postgraduate Research Scheme, Malaysian Ministry of Education and the Universiti Malaysia Pahang (UMP) for providing research grants as well as excellent facilities.

The authors would like to thank Universiti Malaysia Pahang for laboratory facilities as well as additional financial support under Postgraduate Research Scheme grant PGRS200331 and Internal Research grant RDU1903141.

\section{REFERENCES}

[1] Sun W., Jeong R., Young R. et al.: Chemistry of Materials 2007, 19, 104.

https://doi.org/10.1021/cm060223+

[2] Wang Y., Zheng J., Ren G. et al.: Smart Materials and Structures 2011, 20, 045009.

https://doi.org/10.1088/0964-1726/20/4/045009

[3] Gan W., Abd Majid W., Furukawa T.: Polymer 2016, 82,156

https://doi.org/10.1016/j.polymer.2015.11.024

[4] Kumiko A., Masami O., Kohji T.: Polymer 2008, 49, 5186.

https://doi.org/10.1016/j.polymer.2008.09.061

[5] Jianfen Z., Aihua H., Junxing L., Charles C.: Macromolecular Rapid Communications 2007, 28, 2159. https://doi.org/10.1002/marc.200700544

[6] Zhongyang T., Xuemei W., Chao F. et al.: Radiation Physics and Chemistry 2018, 144, 48.

https://doi.org/10.1016/j.radphyschem.2017.10.018

[7] Runfang F., Sheng C., Yi L. et al.: Materials Letters 2017, $187,86$.

https://doi.org/10.1016/j.matlet.2016.10.068

[8] Farah E.A., Boor S.L., Raed H.: Desalination 2015, 356, 15.

https://doi.org/10.1016/j.desal.2014.09.033

[9] Guo-dong K., Yi-ming C.: Journal of Membrane Science 2014, 463, 145.

https://doi.org/10.1016/j.memsci.2014.03.055

[10] Haponska M., Trojanowska A., Nogalska A. et al.: Polymers 2017, 9, 718.

https://doi.org/10.3390/polym9120718

[11] Joshi J.H., Kanchan D.K., Joshi M.J. et al.: Materials Research Bulletin 2017, 93, 63.

https://doi.org/10.1016/j.materresbull.2017.04.013

[12] Rodoplu D., Mutlu M.: Journal of Engineered Fibers and Fabrics 2012, 7, 155892501200700217. https://doi.org/10.1177/155892501200700217

[13] Thandavamoorthy S., Bhat G.S., Tock R.W. et al.: Journal of Applied Polymer Science 2005, 96, 557. https://doi.org/10.1002/app.21481

[14] Weimin X., Zhicheng Z.: IET Nanodielectrics 2018, 1, 17. https://doi.org/10.1049/iet-nde.2018.0001

[15] Kiran K.S., Sharmistha B.: Sensors 2018, 18, 3605. https://doi.org/10.3390/s18113605

[16] Wang Y.R., Zheng J.M., Ren G.Y. et al.: Smart Materials and Structures 2011, 20, 045009. https://doi.org/10.1088/0964-1726/20/4/045009

[17] Satapathy S., Santosh P., Gupta P.K., Varma K.B.R.: Bulletin of Materials Science 2011, 34, 727. https://doi.org/10.1007/s12034-011-0187-0

[18] Jun Y.L., Sehyun K., Yongsok S.: AIP Conference Proceedings 2015, 1664, 0700006. https://doi.org/10.1063/1.4918441

[19] Arshad A.N., Wahid M.H.M., Rusop M. et al.: Journal of Nanomaterials, 2019, 2019, 5961563. https://doi.org/10.1155/2019/5961563 
[20] Gang C.C., Ji S., Leslie J.F.: Journal of Polymer Science Part B: Polymer Physics 1994, 32, 2065. https://doi.org/10.1002/polb.1994.090321213

[21] Bharti V., Kaura T., Nath R.: IEEE Transactions on Dielectrics and Electrical Insulation 1997, 4, 738. https://doi.org/10.1109/94.654689

[22] Damaraju M.D.,Wu S., Jaffe M., Arinzeh T.L.: Biomedical Mater. 2013, 8, 045007. https://doi.org/10.1088/1748-6041/8/4/045007

[23] Hong-Feng G., Zhen-Seng L., Shi-Wu D. et al.: Colloids and Surfaces B: Biointerfaces 2012, 96, 29. https://doi.org/10.1016/j.colsurfb.2012.03.014

[24] Low Y.K.A., Meenubharathi N., Niphadkar N.D. et al.: Journal of Biomaterials Science 2011, 22, 1651. https://doi.org/10.1163/092050610X519471

[25] Wu A.Y., Masaya K., Ye L., Xuehong L.: Polymer 2007, 48, 512. https://doi.org/10.1016/j.polymer.2006.11.036

[26] Mahadeva S.K., Berring J., Walus K., Stoeber B.: Journal of Physics D: Applied Physics 2013, 46, 285305. https://doi.org/10.1088/0022-3727/46/28/285305

[27] Michiko T., Risei W., Masaru O.A., Terutake H.: Journal of Applied Polymer Science 1997, 65, 1517. h t t p s : / d o i o o g / 10.1002 / ( S I C I ) 1097 4628(19970822)65:8<1517::AID-APP9>3.0.CO;2-J

[28] Yuetao Z., Wenyao Y., Yujiu Z. et al.: Journal of Materials Science: Materials in Electronics 2016, 27, 7280. https://doi.org/10.1007/s10854-016-4695-y

[29] Shuaijie W., Liangsen L., Yan Z. et al.: Journal of Adhesion Science and Technology 2015, 29, 678. https://doi.org/10.1080/01694243.2014.1003497

Received 14 IX 2021. 